Personalidade Acadêmica Homenageada:

Raymundo Juliano Feitosa (Universidade Federal do Rio Grande do Norte - UFRN)

\title{
MEDIAÇÃO EMPRESARIAL COMO FORMA DE CUSTOMIZAR A SOLUÇÃO DE CONFLITOS
}

\section{BUSINESS MEDIATION AS A WAY OF CUSTOMIZING CONFLICT SOLUTION}

CAROLINA VALOSKI

Acadêmica de direito do Centro Universitário Curitiba. Curitiba - Paraná. Email. caluvaloski@gmail.com

\section{SANDRA MARA LIMA MACIEL}

Doutora em Sociologia pela Universidade Federal do Paraná (2009). Mestra em Administração pela Universidade Federal do Paraná (2002). Graduada em Ciências Econômicas pela Universidade Federal do Paraná (1993). Coordenadora de Tutoria do Curso de Especialização em Gestão de Organizações Públicas -UFPR/UAB (2012/2014). Líder do Grupo de Pesquisa Observatório sobre Direito à Saúde e Cidadania (CNPq/UNICURITIBA) e Membro do Grupo de Pesquisa em Sociologia da Saúde (CNPq/UFPR). Professora do Mestrado em Direito Empresarial e Cidadania do UNICURITIBA. Fez estágio Pós-Doutoral na Universidade Federal do Paraná (2015/2016). Tem experiência em: Direito à Saúde. Sociologia da Saúde. Subjetividade. Tecnologias Médicas. Políticas Públicas e Metodologia Científica.

\section{RESUMO}

O presente trabalho tem como objetivo fazer uma breve análise sobre a mediação no âmbito empresarial a partir da necessidade de efetivação e contextualização dos conflitos. Este breve estudo usou como método para estudo a pesquisa bibliográfica. 


\section{Personalidade Acadêmica Homenageada:}

Raymundo Juliano Feitosa (Universidade Federal do Rio Grande do Norte - UFRN)

Desde a redemocratização do Brasil em 1988, o poder judiciário brasileiro passa por grandes percalços, uma enorme demanda, uma precária estrutura e nos dias atuais, uma descrença em sua efetividade e moralidade.

Isto porque, na maioria das vezes em que se recorre à judicialização de um problema, é sabido que sua solução virá após, no mínimo, dois anos, prazo este em comarcas tidas como céleres. Essa perspectiva resulta na descrença e até mesmo na desistência de se recorrer ao judiciário.

É a partir desta senda, que o Código de Processo Civil Brasileiro de 2015 passou a incentivar a solução de conflitos de forma não litigiosa, reconhecendo a mediação, a incentivando e ainda prevendo benesses a quem a ela recorre. Exemplo disso é a aplicação do Princípio da Independência, previsto no artigo 166 do CPC/2015.

A mediação é definida como um procedimento de resolução de conflito de forma extrajudicial através de um terceiro imparcial, que será escolhido pelas partes. Conforme a Lei de Mediação (art. 1ํㅗ §único, Lei 13.140/15) este terceiro imparcial é o mediador, que diferentemente de um juiz, não decidirá o mérito de nada, apenas conduzirá as partes a chegar a uma solução juntas.

Na mediação não há a figura antagônica das partes do processo judicial: autor $X$ réu; ganhador $X$ perdedor, existe a figura de uma só parte, envolvida por um só problema que necessita de uma solução conveniente e rápida a ambos. Sendo que esta solução será confeccionada de forma customizada pelas partes de maneira conjunta.

A forma customizada da solução do conflito, com auxilio dos advogados das partes, é o que torna a mediação tão atrativa, isto porque, ela reduz a possibilidades de perdas totais, ela mitiga os riscos e, além disso, conta com a celeridade de um processo extrajudicial.

E é por causa desta mitigação dos riscos é que se vê a aderência dos empresários à solução de conflitos por meio da mediação, essa mitigação é de grande relevância do contexto empresarial porque economiza recursos e tempo, evita à quebra de relações, perdas de lucros e danos. 
Personalidade Acadêmica Homenageada:

Raymundo Juliano Feitosa (Universidade Federal do Rio Grande do Norte - UFRN)

Por fim, ressalta-se que dentro do contexto do judiciário brasileiro "a mediação e a conciliação, tem uma relevante importância là frente na tarefa de reduzir a jurisdicionalização das lides relativas não só aos contratos empresariais, mas a todas as espécies de conflitos" (KFOURI; FATUCH, 2017, p, 130).

PALAVRAS-CHAVES: Mediação; Solução; Litigio; Customizar.

\section{REFERÊNCIAS}

BOTELHO, Inaiá Nogueira Queiroz. Mediação empresarial é um novo caminho para solucionar conflitos e evitar litígios judiciais. Estadão, 2017. Disponível em: $<$ https://politica.estadao.com.br/blogs/fausto-macedo/mediacao-empresarial-e-umnovo-caminho-para-solucionar-conflitos-e-evitar-litigios-judiciais/>. Acesso em: 01 jun. 2019.

BRASIL. Constituição da República Federativa do Brasil de 1988. <http://www.planalto.gov.br/ccivil_03/Constituicao/Constituicao.htm>. Acesso em: 01 jun. 2019.

Lei no 13.140, de 26 de junho de 2015. Disponível em: <http://www.planalto.gov.br/ccivil_03/_ato2015-2018/2015/lei//13140.htm>. Acesso em: 01 jun. 2019.

KFOURI, Miguel Neto, FATUCH, Andrea Neto - A Mediação a Arbitragem e a conciliação para resolução de conflitos empresariais. Revista Jurídica Unicuritiba. Curitiba. V. 16, ํ. 17, p.115-134, 2017. Disponível em: $<$ https://www.unicuritiba.edu.br/images/publicacoes/manual_de_normas_tecnicas.pdf >. Acesso em: 04 jun. 2019. 